\title{
RADICAL FEMINISM IN EKA KURNIAWAN'S NOVEL BEAUTY IS A WOUND
}

\author{
Thesya Widya, Asnani \\ Faculty of Literature, Universitas Islam Sumatera Utara, Medan \\ e-mail: thewid2013@gmail.com
}

\begin{abstract}
This research brings about radical feminism and the role and position of women as pimps. The analysis of this research is fulfilled by using descriptive qualitative research in which the data and the finding of the research are presented and described in a form of description. In this research, radical feminism was revealed in the life of a woman by the name of Dewi Ayu who worked as a prostitute during Japanese colonialism in a warehouse named Mama Kalong Place. Mama Kalong who worked as a pimp served Japanese soldiers in the whorehouse played to make a price for prostitutes. Mama Kalong gave a good shelter and well care to the women in order that they remained healthy and fresh so that they would be ready anytime they were needed. Unfortunately, the pimp did not give the women any protection from any harms which are very possible to befall upon the women. The finding of this research shows that the life of women in colonialism under a pimp is really oppressed. Oppression, suffering, and injustice are with them in the whole life.
\end{abstract}

Keywords: radical feminism, the role and position of women as pimps, Beauty is a Wound.

\section{Introduction}

Women have the primary responsibility for their family's health and food, water and fuel. They always work for unpaid job and largely unrecognized as well. Their major responsibilities for the household do not always mean that they have decision making power within the family (Karl, 1995: 03). Having such condition in many years, women lead to a new movement for women called feminism. Feminism is an ideology which they demand an equal status within the society. It means equal right in terms of politics, decision making, career, and having children.

The Novel Beauty is a Wound, written by Eka Kurniawan (2002) portrays the inability of women to defend their authorization. It exposes how the first character by the name of Dewi Ayu was able to get to know the world of prostitution during the Dutch colonial government for the social reality which forced her to be held up by Japanese soldiers. Her beauty made her famous among men in the Mama Kalong's brothel. She, finally, gave birth to three daughters who exceeded her beauty. Her three daughters also experienced unfortunate fate due to the beauty they had. Finally, Dewi Ayu thought that beauty only brought disaster.

Radical Feminism is a movement founded on the idea that patriarchy is the main cause of discrimination and oppression of women. The radicalism challenges the patriarchal system by demanding women's equality with men in society. Radicalism 
believes that the patriarchal system has given stereotypical stereotypes to impose man's dominance and to make women accept their negative roles in society (Millet, 1970).

Radical feminism seems to be so interested to be analyzed because this issue in the novel is presented in so dramatic way. It also portrays the women's strength to struggle their right. However, this great hope is triggered by the prolonged suffering, oppression, and injustice they experience during the colonialism. Therefore, this research is aimed to uncover the situation and condition of radical feminism during the Japanese colonialism in the novel and to uncover the role and position of a pimp towards the woman in that period which is able to put the women's life in great suffering, oppression and injustice.

\section{Literature Review}

Ratna (2006:186) said that feminism that is used as a tool for women to fight for their rights is closely related to racial conflicts, especially gender conflicts. This means that between class conflict and feminism have parallel assumptions, deconstructs domination and hegemonic systems, conflict between weak groups and stronger groups. Gay in Loobeek (2013:4) said that Feminism is a movement whose primary purpose is to achieve quality, in all realms, between men and women. While, Djajanegara (2000: 16) said that the core purpose of feminism is to increase the status and degree of women to be equal with the position and degree of men. A term of feminism has close relationship with radical feminism. Radical feminism is considered as the beginning of feminism appearance.

Fakih in Khozamah (2015: 20) said that radical feminism is the oppression of women since the beginning of male dominance, where the physical control of women by men is considered as the basic form of oppression. Brownmiller in Masriah (2015: 16) stated that radical feminism is history that appears as a reaction to a culture of sexism or social discrimination based on the sex of the west in the 60s. It is especially important in the fight against sexual violence and pornography. A research found that "the masculine authority uses force against women to protect its power and dominance in the home and society. Thus, women become victims and submissive to men who use them for their own interests. Women are imprisoned so as not to mix with the outside world" (Abd, Hammood, \& Janoory, 2019)

Weedon (1987: 02) states that the followers of radical feminist do not see any difference between the personal and political objectives, sexual or biological elements and conducted and analysis of the causes of the oppression of women by men, they consider it is rooted in the male gender itself and its ideology of patriarchy. Radical feminism sees the oppression of women as a result of the universal value system patriarchy. Patriarchy is a gender system that gives males the privilege to govern and dominate women, while women remain subject to masculine authority. Fatherhood in the traditional sense means the authority of the father or husband over the wife, children and the rest of the family (Bennett, 2006). Patriarchy is a system of structures and institutions created by men in order or sustain and recreate male power and women subordination (Rollin, 1996). The subordination of women in society is derived from the privileged of the male, the rights entrenched in the patriarchal system is claimed in woman's body. The male privilege is not limited to domestic affairs, but also extends to economic aspect, political, cultural, and others. Such patriarchal culture has reached the whole of society from top to the bottom. The existing system in a society that is based on sex/gender so that the way they think and the knowledge they have also formed following their 
experience as a creature with a specific gender. This thought affects the judgment against the women sexuality that must follow and meet the desires of men, whether in marriage, reproduction, and prostitution. Prostitution in general is the practice of relationships sexual moment, which is more or less done by anyone for reward in the form of money. The three main elements in the practice of prostitution are: Payment, Promiscuity, and Emotional indifference. Koentjoro (2004: 19) explains that commercial sex is part of extra-marital sex activities marked by satisfaction from various people involving several man done for money and used as a source of income. Anwar and Andang (2010: 361362 ) explains the term prostitution as an activity where women give their body and gain profits for satisfying the sexual urges of men. Siregar (2015: 1-3) explains prostitution can also be interpreted as a self-surrendering or selling service to the public to do sexual acts with get rewards according to what was agreed before.

\section{Research Method}

This research chooses a qualitative descriptive as the design of the analyzing the data. According to Creswell (2009: 3) research design is a method for a research to fulfil the data collection and analysis. The data collection is completed by some steps, namely reading Beauty is a Wound novel repeatedly, understanding the story of the novel, finding out the data, and writing down the significance notes in the novel Beauty is a Wound.

The data is then analyzed in some steps as well. They are identifying data, categorizing and classifying all data in the novel, describing and interpreting data, organizing the whole data, and making conclusion based on the analyzed data.

\section{Discussion}

\subsection{Radical Feminism}

The novel, Beauty is a Wound, talks about a wound encountered by women during the Japanese colonialism.

She saw military trucks lined up on the beach, ready to round up all the remaining Dutch inhabitants and take them to a prison camp. Look, she said to another woman next to her, they must be confused by two foreign nations making war on their land. The day before, the soldiers had come to their houses and ordered them to pack. She didn't take any money or jewelry, because she knew all that would just get stolen. (Kurniawan, 2012: 55).

The soldiers will capture all of the remaining Dutch women and take them into the prison. Before sending them to a prison, the soldiers collects all of their remaining valuables.

The women walked toward the prison, passing through three iron gates guarded by soldiers. Before entering, they lined up in front of a table where two Japanese men sat clutching a list. Next to them there was a basket for money and valuables. A number of women were already taking off their jewelry and tossing it in." Do it before we search you." (Kurniawan, 2012: 61).

All women get in to the prison. They did not find any happiness inside it. All their happiness and habits have been lost. They could only surrender to the situation. 
"It can believed, that we are leaving our own houses behind!" said the women next to her." I hope it won't be for long." I hope that our army can beat back the Japanese, otherwise we are going to be traded like sugar and rice," Said Dewi Ayu. (Kurniawan, 2012: 58).

They could only accept the situation as if there were no hope for life. In prison they are not given any food and clothes. Dewi Ayu, one of the prisoners, looks for something to eat; she eats leeches to fill her empty stomach.

"No one was interested in eating leeches, and one woman practically retched at the very thought of such a meal. We're not eating the leeches, but cow's blood, Dewi Ayu explained. She split open the leeches with a small knife, pulled out the clots of cow's blood inside them, stabbed them with the point of knife, and swallowed them." (Kurniawan, 2012: 63).

One of them is an Ola figure who asks for medicine and doctor to cure her mother who is sick in the prison. In order to get the medicine, she is asked to have sex for a pack of medicine and a doctor. It can be seen the following quotation.

"Let her die, she said sobbing. What did you say?! Asked Dewi Ayu. Ola shook her head weakly while wiping away her tears with her sleeve. There's no way, she said shortly. The commandant would only give me medicine if I agree sleep with him. (Kurniawan, 2012: 67)

The condition requires them to surrender. Women are very oppressed, they cannot fight against men. They are only made to satisfy desires and passions.

"He smiled, cunning and predatory feeling like a lucky old man in deed.

This young girl was very pretty, no older than seventeen or eighteen, maybe still a virgin, and she was offering herself to him just for some fever medicine and doctor. (Kurniawan, 2012: 67).

Men look smart and powerful. They use weak and helpless women to satisfy their lusts. After being imprisoned, they were taken to a very large and luxurious house. The house was once a Dutch family. Now the house is called Mama Kalong house. They thought they would volunteer for the Japanese soldiers, but the truth is that they will become sex slaves.

They were ordered to go their rooms while a number of Japanese men lined up at a table on the veranda to buy their tickets. The first night the prices were very expensive, because they believed that the girls were still virgins. Then the soldiers began to capture the girls one by one, in a battle they won with easy, gripping the girls in their hands like sick kittens thrashing about futilely as they were being taken away. (Kurniawan, 2012: $85)$.

The life they experienced is very sad. Happiness and future are destroyed. They are promised to volunteer, but instead they are made as sex slaves for the soldiers. They are really helpless. What they experienced is very painful. After bathing, they are forced to go back to their rooms to do it again.

That night they were taken by four or five men each. That was a crazy night. What made Dewi Ayu suffer was not the crazy tireless screwing that 
froze her body in a quiet and mysterious paralysis, but the screams and sobs of her friends. You poor women, she thought. Fighting against the inevitable hurts worse than anything else. (Kurniawan, 2012: 87).

The oppression they experienced is cruel. They are forced into prostitutes. At one time, they are raped by four to five soldiers, while there are still more soldiers who buy tickets to wait for their turn. That afternoon becomes something they cannot forget. They think of taking revenge on the soldiers for what they have done. They are harassed and not paid at all, even if they fight and try to escape, they will be forcibly withdrawn by the soldier again. The first week, they are too ashamed to talk to one another, and they lock themselves up in their rooms, pass their time cry alone. Except Dewi Ayu who is still calm. It seems that she has no desire to rebel. After one month in that whorehouse, Dewi Ayu is the first woman to get pregnant. Mama Kalong advised her to abort her fetus, but Dewi Ayu refuses.

Think of your family, Mama Kalong said. Dewi Ayu then replied, "Just as you are telling me to do, Mama, I am thing of my family, and the only family I have is this kid inside me". So Dewi Ayu lets her stomach stick out, and get bigger day by day (Kurniawan, 2012: 89).

It is seen that Dewi Ayu is pregnant, and when Mama Kalong knows it, she is told to abort her fetus, instead of helping treatment. It happens as the result of her actions; Mama Kalong has made them as prostitutes. Dewi Ayu lets her stomach puff up, and bigger day by day. Dewi Ayu thinks she will give the name Alamanda to her child. The situation gives good luck to her because no one was allowed to sleep with her. No Japanese even wants to sleep with her in that condition. Meanwhile, the war is not over yet. The Japanese troops have finished building defense trenches along the southern coast. Mama Kalong has given the girls radio so that they hear that two bombs have fallen on Japan. Japan has lost. British troops control the cities then. And Japanese soldiers left guard the house. After that bad luck comes to them again when a guerrilla raid of native troops attack them, they get oppressed again. It can be seen the following quotation.

There were more than guerrillas, and they gathered all the prisoners. When they discovered that all of them were women and all of them were Dutch, the men grew even more violent. They tied up some of the women in the kitchen, and the other were dragged off to the bedrooms to be raped. Their cries were even more heart breaking than when the Japanese had turned them into whores. (Kurniawan,2012:96).

The suffering they experienced is endless, from the Japanese colonial era, to British rule. They still get sexual oppression. They are raped by force. The violence they experienced was not only in physical, but also inner conflict.

\subsection{The Role and Position of Pimps (Mama Kalong)}

In the novel Beauty is Wound by Eka Kurniawan, the female character has different roles. The author writes himself about a description of women who works as pimps in process of trafficking. Mama Kalong is a character who played prostitute service during the colonialism, selling water, palm wine and rice for the soldiers. Besides, she also uses girls who are still virgin to become prostitutes. She expanded and built rooms of woven bamboo as a place of prostitution. It can be seen the following quotation. 
By the end of the first month she had already found two young girls around twelve or thirteen years old to help her at the tavern, both as waitresses and as whores. She had begun her career as a pimp. After three months, there were six whores there, not including herself, enough for her to expand the tavern, building a few rooms with walls made from plaited bamboo. (Kurniawan, 2012: 81).

Mama Kalong starts her career as pimp since she gets two young girls around twelve or thirteen years to accompany and live with her at the tavern, both as waitresses and whores. Previously, she was just a girl who helped out at the tavern owned by her aunt. After closing the tavern, she goes to the barracks. She knows what they need and they know what she wants. The soldiers pay her to straddle their laps naked. Three or four of them would take turns screwing her before she goes home with their money. After a while, she begins to pull in way more than what her aunt was making. She has a good business instinct. Then she opens her own tavern. This is where she begins to search for girls to accompany her as the servants of prostitute. It can be seen the following quotation.

One day, after getting scolded for falling asleep at work, she left her aunt and opened up her own tavern at the end of the wharf. She sold rice, palmwine and cane sugar and also her own body. By the end of the first month, she had already found two young girl around twelve or thirteen years old to help her at the tavern, both as waitresses and as whores. She had begun her career as a madam. (Kurniawan,2012:81).

Before she becomes a pimp, she has already sold herself to the soldiers. Dewi Ayu and her friends are in a force by sleigh soldiers to board the ferry, then takes them into the trucks to get the trip of Halimunda city. They come to a place called Mama Kalong. It can be seen the following quotation.

Is this your house, Miss? Asked Dewi Ayu politely. Call me Mama Kalong, she said. Because like a kalong, a fruit bat, I'm much more often up and about at night that during the day. She came down off the veranda and approach the women, trying to lighten the bleak expression on their faces with a joke and a smile (Kurniawan, 2012: 75).

Dewi Ayu and her friends are cheated. They think they will be volunteer for the Japanese soldiers, but the truth is that they become sex slaves. The place is known as Mama Kalong's whorehouse. One day, Japanese military officials want to separate prostitutes, moreover prostitutes are often used by port workers and fishermen. Mama Kalong must make haste to find those girls, and after getting them. She raises the price on them because they are still virgin. It can be seen the following quotation.

It's easy sir, she said, to find girls like that. Tell me, where? The prisoners of war, replied Mama Kalong shortly. The prostitutes were given the best care by Mama Kalong (Kurniawan,2012:84).

She has a good instinct. It can be seen from how easily she gets new girls who are still virgins. According to the request of the general, and she is also good at taking care of her girls so she can get more expensive payments. Despite Mama Kalong has a good side to her prostitutes, she treats her prostitutes well because she knows that the most exquisite pleasure is to be found in a healthy body. It can be seen the following quotation. 
She never wanted to make her young prostitutes suffer. In fact quite the opposite, she tended to spoil them, like a granny taking care of a horde of grandchildren. She had servants who would heat warm water for them so that they could bathe after exhausting lovemaking sessions. On certain days, she gave them the day off and took them on outings to a nearby waterfall. She brought in the best tailors to make their clothes, and above all, their health was her highest priority. (Kurniawan, 2002: 83).

Mama Kalong has a great responsibility to the prostitutes. They are made like queens and filled with their desires and needs. It is felt by Dewi Ayu. She accepts the risk during in brothel, and Mama Kalong is responsible for it. She moves her to another room.

Mama Kalong told her to stay in a back room and announced to all the Japanese that she was pregnant and no one was allowed to sleep with her. No Japanese even wanted to sleep with her in that condition, and so she urged the other girls to follow her lead. (Kurniawan, 2002: 89).

Mama Kalong is greedy, but she never wants to make her young prostitutes suffer. Mama Kalong is still making sure that they are fine. She also entertains them and gives clothes to them so that they sew little clothes for their babies. At least, it spares them the boredom of waiting for the war to end. It can be seen the following quotation.

Mama Kalong still invited the girls to take advantage of the excellent care she could provide them. I treat all my whores like queens, she said with pride. I don't care if they are already retired. They filled their days, weeks, and months entertaining themselves with Dewi Ayu, who continued to sew for her baby. With to help of her friends, she already had almost one full basked of small articles of clothing, made from the fabric they had found in the household closets. At least it spared the boredom of waiting for the war to end, until finally Mama Kalong came with a midwife. All of my prostitutes who have ever gotten pregnant have given birth with her help, said Mama Kalong. (Kurniawan, 2002: 93).

Trafficking is possible to occur when women at first did not know and did not aware about it until finally they are realized that they are employed by labor suppliers as sex workers. This happens to Dewi Ayu and her friends in Mama Kalong place. Mama Kalong is a greedy woman who never wants to make the girls working for her suffer. She tends to spoil them, like a granny taking care of a horde of grandchildren. On certain days, she gives them the day off and took them on outings to a nearby waterfall. She brings the best tailors to make their clothes. Their health is her highest priority. They are treated like queens. She is responsible for the pregnant and advantage of the excellent care she is able to provide them.

\section{Conclusion}

The women's life in the novel, Beauty is a Wound by Eka Kurniawan reflects an oppression, suffering, and injustice befell upon the women worked as prostitutes in Mama Kalong Place. The bad life of the women is dominantly direct to sexual oppression which is under control of a pimp who leads them to suffer and live in injustice. 


\section{References}

Abd, Z., Hammood, A., \& Janoory, L. Bin. (2019). Bedouin Women Status under the Patriarchal System in Miral Al Tahawi' S the Tent, 3(1), 10-20. https://doi.org/10.30743/ll.v3i1.1174

Anwar and Andang. (2010). Kriminology. Refleksi Aditama: Bandung.

Bennett, J. M. (2006) History matters: patriarchy and the challenge of feminism. Philadelphia: University of Pennsylvania Press.

Creswell, John W. (2009). Research Design : Qualitative, Quantitative, and Mixed Methods Approaches. Newbury Park: Sage Publications.

Djajanegara, Soenarjati. (2000). Kritik Sastra Feminis: Sebuah Pengantar. Jakarta: Gramedia

Fakih, Mansour. (2015). Analysis Gender Dan Transformasi Sosial. Yogyakarta: Pustaka Pelajar

Karl, M. (1995). “Women and Empowerment: Participation and Decition Making. London: Zed book Ltd.

Koentjoro. (2004). On The Spot: Tutur Dari Sang Pelacur. Yogyakarta: Tinta, Hlm. 36.

Loobek, Kristy. (2013). "A feminist analysis of the film The Hunger Games" Concordia University, St. Paul.

Masriah. (2015). "Sikap Radikal Tokoh Perempuan Dalam Si Parasit LajanKarya Ayu Utami" Jurusan bahasa dan sastra indonesia, fakultas bahasa dan seni, Universitas Negeri Yogyakarta.

Millett, K. (1970). "Theory of Sexual Politics" In Radical Feminism: A Documentary Reader. Ed. Barbara Crow. New York: New York University Press. P,26-55.

Ratna, Nyoman Kutha. (2004). Teori, Metode, dan teknik Penelitian Sastra. Yogyakarta: Pustaka Pelajar.

Rollins, Joan H. (1996). Women's Minds Women's Bodies The Psychology of Women in a Biosocial Context. USA: Prentice-Hall

Kondar Siregar, MA. (2015). Model Pengaturan Hukum Tentang Pencegahan Tindak Prostitusi Berbasis Masyarakat Adat Dalihan Na Tolu, Prenada Media Handalan, Hal 1-3.

Weedon, C. (1987). Feminist Practice and Postructuralist Theory. Oxford: Blackwell. 